\title{
Corporate Governance Rules in Six Stock Exchanges: A Comparative Study
}

\author{
Hong Yuh Ching \\ Centro Universitário da FEI, Av. Humberto de Alencar Castelo Branco \\ 3972, São Bernardo do Campo, Brazil \\ Renan Tardelli \\ Centro Universitário da FEI, Av. Humberto de Alencar Castelo Branco \\ 3972, São Bernardo do Campo, Brazil
}

\begin{abstract}
This paper aims to compare the corporate governance rules around the world and to ascertain which Stock Exchange SE is more adherent to our proposed corporate governance framework. The SE researched were Tokyo TSE, New York NYSE, Frankfurt Stock Exchange, Brazil BM\&FBovespa, London Stock Exchange and Toronto TSX. Several governance models or frameworks extracted from the literature were analyzed, however the integration across these studies showed extremely difficult. This lead us to build our own "proxy" framework composed of 15 rules. TSX has the lowest corporate governance standard compared to other five SE because its document does not provide description in 12 rules out of 15, while London has the highest corporate governance standard with detailed description in 11 rules. As more and more companies do business around the world with their counterparts and governments, it becomes increasingly important to understand the similarities and differences between the corporate governance rules and practices in some Stock Exchange around the world.
\end{abstract}

Keywords: corporate governance, governance rules, stock exchange, corporate value.

\section{INTRODUCTION}

The disclosure of information by the companies, financial and non-financial, is essential for investors in their process of decision-making. Therefore, its disclosure in an objective and transparent way may enable a higher degree of reliability when one is making an investment decision over another. Companies, in general, should be worried in creating an efficient set of mechanisms to ensure that the behavior of the managers is aligned with the best interest of the company.

However, this might not be the case of many companies. Reaz and Hossain [1] discussed the idea of separation of power between the executive management of major public companies and their shareholders. This is known as the "principal-agent" problem. It tends to plague the relationship between shareholders (the principals) and managers (the agents) owing to the separation of ownership and management (or control) in companies with widely dispersed "public" ownership of shares (Oman, Fries and Buiter) [2]. These authors raised another conflict of interest, the "expropriation problem", between controlling shareholders on one hand and minority shareholders (domestic and foreign), and other investors, on the other. The expropriation problem, as distinct from the "agency" problem, tends to prevail, worldwide, in countries with highly concentrated structures of corporate ownership. 
Corporate governance can be defined as the structures and processes by which companies are directed and controlled. Good corporate governance helps companies operate more efficiently, mitigate risk and safeguard against mismanagement, and improve access to capital that will fuel their growth (IFC International Finance Corporation) [3].

For IBGC Instituto Brasileiro de Governança Corporativa [4], the basic principles of Corporate Governance are:

1. Transparency - provide interested parties with information that is of interest, and not merely those imposed by laws or regulations. It should not be restricted to the economic and financial performance, but also consider other tangible and intangible factors that guide managerial action and lead to the creation of value.

2. Fairness - A fair treatment of all shareholders and other stakeholders. Discriminatory attitudes or policies, under any pretext, are entirely unacceptable.

3. Accountability - The agents of governance should be accountable for their actions, undertaking the full consequences of their acts and omissions.

4. Corporate Responsibility - The agents of governance should watch over the sustainability of their organizations, to ensure their company's longevity, by observing social and environmental principles when identifying business deals and operations.

OECD Organization for Economic Co-operation and Development [5] principles, however, cover six key areas of corporate governance - ensuring the basis for an effective corporate governance framework; the rights of shareholders; the equitable treatment of shareholders; the role of stakeholders in corporate governance; disclosure and transparency; and the responsibilities of the board. These principles are more comprehensive than those of IBGC [4] for covering more areas.

Academics, practitioners and policy makers have demonstrated a dramatically increased interest in systems of corporate governance, especially after the collapse of the centrally planned economies. This growth was noticed by Gillan [6]. In a search of SSRN (Social Sciences Research Network) abstracts containing the term corporate governance, it resulted in more than 3500 hits, the authors of this article performed same search in 2014 and resulted in 11500 hits.

The argument to sustain a higher level of disclosure by the companies, regardless of being mandatory or no is the expected positive repercussion of the information at the Stock Exchange Markets, contributing to a better financial assessment of the corporations. Lower cost of capital, higher return, less stock price volatility are some of positive repercussions (Malacrida and Yamamoto) [7].

To address to investors, some Stock Exchanges SE have separate level of market listing that includes only firms with higher level of transparency, which can be understood as corporate governance level. Examples of these separate indexes are DAX, MDAX, TecDAX and SDAX of Frankfurt Stock Exchange, IGCX, IGCT and IGC-NM of BMF\&BOVESPA (São Paulo) and FTSE 100, FTSE 250, FTSE Small Cap and FTSE Fledgling of London Stock Exchange. Going in the same direction, many Stock Exchanges around the world do have corporate governance codes or rules to be followed by the corporations listed.

Having this in mind, this paper aims to compare the corporate governance rules around the world and to ascertain which SE is more adherent to our proposed corporate governance framework. We chose six Stock Exchange, five from developed countries and one from a 
developing country. The SE researched were Tokyo Stock Exchange, New York Stock Exchange, Frankfurt Stock Exchange, BM\&FBovespa (Brazil), Toronto Stock Exchange and London Stock Exchange.

\section{LITERATURE REVIEW}

IFC [3] defines corporate governance as the structures and processes by which companies are directed and controlled. Good corporate governance helps companies operate more efficiently, improve access to capital, mitigate risk and safeguard against mismanagement. It makes companies more accountable and transparent to investors and gives them the tools to respond to stakeholder concerns. Corporate governance also contributes to development. Increased access to capital encourages new investments, boosts economic growth, and provides employment opportunities.

For Becht et al., [8] corporate governance is concerned with the resolution of collective action problems among dispersed investors and the reconciliation of conflicts of interest between various corporate claimholders. In a more expanded definition, Gregory [9] states that corporate governance refers to that blend of law, regulation, and appropriate voluntary private-sector practices which enables the corporation to attract financial and human capital, perform efficiently, and thereby perpetuate itself by generating long-term economic value for its shareholders, while respecting the interests of stakeholders and society as a whole.

In FRC Financial Reporting Council Code [10], the purpose of corporate governance is to facilitate effective, entrepreneurial and prudent management that can deliver the long-term success of the company. Corporate governance comprises a country's private and public institutions, both formal and informal, which together govern the relationship between the people who manage corporations ("corporate insiders") and all others who invest resources in corporations in the country [5].

From the above definitions, it is clear that there is not a common definition of corporate governance CG. Gregory [9] is the only author that associates CG to a blend of law, regulation and voluntary private sector practices while the other authors/institutions do not mention law or regulation. CG is mostly ruled by voluntary private sector practices. All these definitions are focused on long-term success or economic value of the company (or alike) and its shareholders. Other common terms in these definitions are transparency and accountability of the different parties to avoid conflict between the shareholders, the people who manage corporations (agents) and the company's stakeholders/claimholders. Final comment is on the last part of OECD [5] definition regarding on who invest resources in corporations. Did OECD deliberately leave it open? Before discussing "who", the discussion should start with "what resources"? If the resource is money, no doubt the person is the shareholder/investor. However if we expand to materials, equipments, intellectual capital, land, then we are referring to different stakeholders.

\section{Correlated studies regarding corporate governance and the firms' results}

Corporate governance improve access to capital as an increasing volume of empirical evidence indicates that well governed companies are positively correlated with market valuation and operating performance (Klapper and Love) [11]. For them, performance improve as improved governance structures and processes help ensure quality decision-making, encourage effective succession planning for senior management and enhance the long-term prosperity of companies, independent of the type of company and its sources of finance. They also found that firms in countries with weak overall legal systems have on average lower governance rankings. 
Poor standards of governance, particularly in the area of transparency and disclosure, have been a major factor behind instability in the financial markets across the globe (Claessens and Laeven) [12]. In their dataset of 45 countries, they found that financial development facilitates economic growth through greater availability of external financing. For La Porta et al. [13], when outside investors finance firms, they face a risk that the returns on their investments will never materialize because the controlling shareholders or managers expropriate them. Using investor protection as the starting point appears to be a more fruitful way to describe differences in corporate governance regimes across countries.

Finally, Malacrida and Yamamoto [7] analyzed the relationship between disclosure and stock price volatility of 42 firms listed at BM\&FBovespa and indicated that the companies with better average accounting disclosure presented lower mean volatility levels.

\section{Correlated studies on corporate governance rules}

Gompers et al. [14] studied the relationship between shareholder rights and firm value by building a "governance index" of 24 governance rules. Their main data source was the IRRC (Investor Responsibility Research Center) for the period of 1990 until 1998. They found that firms with stronger shareholder rights had higher firm value, higher profits, and higher sales growth, lower capital expenditures and made fewer corporate acquisitions. They concluded that an investment strategy that bought firms in the lowest decile of the index (strongest rights) and sold firms in the highest decile of the index (weakest rights) would have earned abnormal returns of 8.5 percent per year during the sample period.

Using the ISS database (Institutional Shareholders Service) Chung et al. [15] selected 24 governance rules in six categories and found that firms with better corporate governance have narrower spreads, higher market quality index, smaller price impact of trades, and lower probability of information-based trading. Their conclusion was that firms may alleviate information-based trading and improve stock market liquidity by adopting corporate governance standards that mitigate informational asymmetries.

Larcker et al. [16] initially started in their model with 39 structural measures of corporate governance. Using exploratory principal component analysis, they identified the underlying dimensions or structures of corporate governance and determined which indicators are associated which each factors. This resulted in 14 factors or governance constructs, such as Board Variables, Stock Ownership Variables, Institutional Ownership Variables, Activist Variables, Debt Variables, Compensation Mix Variables and Anti-Takeover Variables. They found that their corporate governance constructs have some association with measures of managerial decision-making, firm performance and valuation.

Bebchuk et al. [17] put forward an entrenchment index based on six provisions: staggered boards, limits to shareholder bylaw amendments, poison pills, golden parachutes, and supermajority requirements for mergers and charter amendments. They found that increases in the index level are monotonically associated with economically significant reductions in firm valuation as well as large negative abnormal returns during the 1990-2003 period. Adding more provisions to an index is hardly bound to be beneficial, in this area less can be more. Shareholders and their advisers might do well to focus on those corporate governance provisions that really matter for firm value.

Comparing all the different set of corporate governance variables/rules utilized by the above authors, we found that only one governance rule is common between them, that is the 
existence or no of poison pill for anti-takeover. Each study or paper tends to use a different set of corporate governance variables. The conclusion is that the integration across these studies becomes extremely difficult.

Since we were not able to harmonize a set of standard governance rules from these studies in order to build our own "proxy" framework, we took as reference a comparison of corporate governance codes relevant to European Union. In this study, Gregory [9] used 36 governance codes or rules, of which we selected 15 rules for our framework. These are the following:

1. Board Membership Criteria - the board is composed in such a manner that it is capable of handling its managerial tasks, and that it acts as a constructive and qualified sparring partner for the management at the same time.

2. Separation of Chairman and CEO - The positions of chief executive officer and chairman of the board should preferably be distinct.

3. Lead Director - If the chairmanship of these governing bodies is entrusted to the same person, it is necessary to ensure that there are one or more prominent individuals on the Board of Directors who can form a counter-balance to the influence of the chairman.

4. Board Size - It is important that the board has a size which allows for a constructive debate and an efficient decision process, in which it is possible for all the directors to play an active part.

5. Mix of Inside and Outside Directors - Boards should consider assigning a sufficient number of non-executive board members capable of exercising independent judgment to tasks where there is a potential for conflict of interest.

6. Term Limits - It is recommended that directors are elected to the board for a defined period.

7. Executive Sessions of Outside Directors - the Supervisory Board meets at times for one sitting per year without the Management Board.

8. Number of Committees - The forming of working groups ("committees") from the external members should be discussed at least by the Boards of Directors of listed companies. Such working groups would be, e.g., the Auditing Committee and the Nomination and Remuneration Committee of the top management.

9. Committees Structure - Refers to the number of members in each committee.

10. Independence of the Committees - If there is an appointment committee, it should be composed mostly of non-executive directors and chaired by the Chairman of the Board of Directors or by a non-executive director.

11. Formal Evaluation of the CEO - The remuneration committee is expected to select appropriate performance measures for evaluating and remunerating the CEO and other executive directors, and satisfy itself that relevant performance measures have been fully met.

12. Executive Compensation - The remuneration committee is expected to select appropriate performance measures for evaluating and remunerating the CEO and other executive directors, and satisfy itself that relevant performance measures have been fully met.

13. Content and Character of Disclosure - Disclosure should include, but not be limited to, material information on:

a) Major share ownership.

b) Members of the board and key executives and their remuneration.

c) Governance structures and policies.

14. Shareholder Voting Practices - The principle of "one share, one vote" is the basis of the right to vote. Shareholders should have the right to vote at general meetings in proportion to the issued shareholder capital. 
15. Anti-Takeover Devices - Shareholders have the right to participate in, and to be sufficiently informed on extraordinary transactions that in effect result in the sale of the company.

\section{METHODOLOGY}

This is a descriptive analysis because it intends to describe the differences among the corporate governance rules of several Stock Exchange SE around the world. The study was based on corporate governance rules documents of Stock Exchange from BM\&FBovespa [18], New York Stock Exchange [19], German Government Commission [20], Tokyo Stock Exchange [21], Financial Reporting Council [22] and Ontario Securities Commission [23]. These documents were downloaded from their respective websites.

\section{DISCUSSION OF THE RESULTS}

The results can be seen in appendix 1. The names of the Stock Exchanges were shortened to TSE for Tokyo, NYSE for New York, NM for BM\&FBOVESPA, Frankfurt for Frankfurt Stock Exchange, TSX for Toronto and London for London Stock Exchange.

We can notice that TSX has the lowest corporate governance standard compared to other five SE because its document does not provide description in 12 rules out of 15 . On the other extreme, we find London with the highest corporate governance standard with detailed description in 11 rules. Regarding governance rules, one of them (lead director) displayed no description in all the six SE. Finally, two rules (mix of inside and outside directors and Content and Character of Disclosure) have detailed description in four SE.

\section{Characteristics of New York Stock Exchange, NYSE}

The basic framework of NYSE governance rules is driven to the objective of maximizing shareholers'wealth and protecting their interests. Reaz and Hossain [1] also share this view in his study. Dempsey [24] states that NYSE regime emphasizes the rights of shareholders to vote on major company decisions and to elect a board of directors.

NYSE provides specific corporate governance rules and practices that listed companies must follow despite they follow regulations and other guidance promulgated by the SEC (Securities Exchange Committee). US companies listed on NYSE must comply with a broad range of corporate governance rules. Some of these rules require that a company maintains at least three committees, being the audit committee, a corporate governance and a compensation committee, each consisting of independent directors.

This requirement of at least 3 committees balances the relative freedom that companies may have to constitute the Board of Directors and ensures to shareholders a proper supervision of the activities performed by the company. In the rule Mix of inside and outside directors, NYSE requires that majority of directors be independent or outsiders, however the company has relative freedom to compose the number of inside and outside directors. Nevertheless, some big companies adopt more rigid standards, such as Wal-Mart, Coca Cola and JP Morgan that have only one inside director. This attitude gives more credit to their actions making the company attractive to investors.

The Board of Directors is elected by the shareholders and is responsible for setting the direction and policy of the company as well as appointing its management. Regarding its size, NYSE is not prescriptive leaving it to the company's choice. To illustrate, Procter \& Gamble has 
nine members, JP Morgan has eleven members while Wal-Mart and Coca Cola have 15 members.

Other similar characteristic is in the rule Separation of Chairman and Chief Executive Officer CEO where NYSE does not have such demand. This practice, if misconducted, may limit the Board's power and centralize it in the hands of one person. Coca Cola, JP Morgan and Procter \& Gamble have same executive for both positions, but JP Morgan has an independent Lead Director, which makes the power more balanced in some controversial issues.

In another governance rule, Executive sessions of independent directors, NYSE requires an annual regularly scheduled board meeting at which only independent and/or non-executive directors are present. Finally, the compensation committee reviews and approves the formal evaluation of the CEO as well as determines the compensation of all directors of the Board. The companies should disclose their director's compensation in a statement of form filed by the company with the SEC.

\section{Characteristics of Novo Mercado, NM (Brazilian Stock Exchange)}

Novo Mercado Corporate Governance Equity Index is a portfolio composed of stocks of companies that have a good level of corporate governance and are listed on BM\&FBovespa. Its initial listing is dated of 2002 and has on September 2014 around 90 companies listed with a market capitalization of US\$344, 5 billion. Brazil, as a developing country, seeks constantly investment, mainly foreign investment, into trade and industry. Corporate governance plays an important role in tapping investment by boosting investor's confidence, and this equity index is part of BM\&FBovespa' strategy to attract local and foreign investors.

To be part of NM index, the companies' equity must be exclusively composed of ordinary shares, which makes this SE unique. This may allow a low ownership concentration, similar to what happens in US equity market. Another characteristic of NM, the companies listed in this index have to maintain minimum of $25 \%$ of shares free float and to publish their financial demonstrations in accordance to IFRS (International Financial Reporting Standards). To protect the minority shareholders, in the case of sale of company' control or as part of antitakeover device (rule 15), they are entitled to a tag along of $100 \%$, ie, they have the right to sell the shares at same price of the majority shareholders.

In the rule Mix of inside and outside directors in the Board, NM requires a minimum of $20 \%$ of independent directors. The majority of companies listed is following this rule. Cielo has $27 \%$, Sonae Sierra has 25\%, JSL with 40\% and Fleury with 28\%. Regarding Board size, NM demands minimum of five members. Cielo have eleven members, while Sonae Sierra has eight, JSL has five members and Fleury with 7 members, all of them have a term limit of two years maximum. Moreover, NM demands separation of Chairman of the Board and the CEO.

The Brazilian corporate governance did not show a high standard in comparison with NYSE or Frankfurt, but it has many characteristics of our proxy not covered by NYSE and Frankfurt. Like the prescription of a minimum Board Size and most important the mandatory Separation of Chairman and CEO.

Finally, we could not identify a clear characteristic of NM framework, like NYSE driven to the objective of maximizing shareholders' wealth or Frankfurt to protect the stakeholders. Nevertheless, as said initially, it has a high corporate governance standard and it serves the purpose to boost investor's confidence. 


\section{Characteristics of Frankfurt Stock Exchange}

Frankfurt Stock Exchange is the only of the four Stock Exchange analyzed that has a Code of corporate governance, while the other three have a document containing rules for listing. Its code presents essential statutory regulations for the management and supervision of German listed companies [20]. A unique characteristic is the dual board system comprising a Management Board and a Supervisory Board. The Management Board is responsible for managing the company, the Supervisory Board appoints, supervises and advises the member of the Management Board and is directly involved in fundamental decisions of the company. The members of the Supervisory Board are elected by the shareholders, however the employees are also represented in this Board from one third to half of the members, depending the number of employees [20]. This concerning with employees is a characteristic of Frankfurt Stock Exchange, indeed, It's the only SE that set among Management Board responsibilities the diversity, of men and women, when filling managerial positions.

Frankfurt requires only two committees, being the audit and nominating. The chairman of the audit committee should not be a former member of the Management Board and members of the Nominating should be formed exclusively by shareholders representatives.

The Management Board shall be comprised of several members. However, looking the Board of Bayer, Allianz, Adidas and Siemens, they have less members than those companies in NYSE or TSE. Bayer and Adidas have 5 members, Siemens 7 and Allianz 11 members. This can be explained by the existence of a Supervisory Board working very closely with Management Board. Finally, one similar characteristic with NYSE and TSE is that there is no separation between Chairman of the Management Board and CEO. This is the practice in Adidas and Allianz, for instance.

German Government Commission [20] states its purpose is to promote the trust of International and national investors, customers, employees in the management and supervision of listed companies.

\section{Characteristics of Tokyo Stock Exchange, TSE}

Reaz and Hossain [1] states that the cultural dimension of the corporate governance and the family values drive the Japanese governance system. This fact might be the reason why crossholdings between financial and non-financial companies are the trademark of the Japanese ownership structure and thus, the ownership is widely dispersed.

Tokyo Stock Exchange [21] is not prescriptive, it lacks clarity in the description of the corporate governance rules. For instance, in the rule Number of Directors, this document shows the average number of persons per listed company and, yet, in 472 companies, there are more than 5 directors. Canon has 19 members, Softbank has 10 members, Sumitomo 15 members and Mizuho 13 members.

Regarding the number of independent directors in the Board, the average number is 1.02 outside director per company. However, the percentage of companies whose number of outside directors having a seat on the board of directors occupies more than one-third. This seems to be the case of Softbank with 3 independent directors and Mizuho with 6 outsiders. Canon and Sumitomo have only 2 independent members.

Companies with committees in TSE are required to establish 3 committees, being the nomination the largest (with average of 4.04 members), the compensation with 3.73 members 
and audit committee with 3.71 members. As far as independence of committees is concerned, the majority of members must be outside directors.

Finally, the president chairs the Board of directors in 78.9\% of TSE-listed companies followed by the company Chairman in $19.7 \%$ of the companies. Among the companies surveyed, only Sumitomo has this separation.

Tokyo Stock Exchange, has lower corporate governance standards; it fulfills 5 out of 15 governance rules. Despite this lack of prescription, the Tokyo Stock Exchange [21] mentions that there is growing awareness that the intrinsic purpose of corporate governance is to improve corporate value.

\section{Characteristics of London Stock Exchange}

London Stock Exchange, alongside with Frankfurt Stock Exchange, counts with a Corporate Governance Code, but it is the only SE that shares its code with other countries of United Kingdom, because it is UK Corporate Governance Code.

The Management Board of London SE is the only SE that has a Board Membership criteria. It says is "Based on Merit", although not specific, but it is still the only document that shows this concern.

Board Size is not very prescriptive since it determines a "sufficient" size. We took few cases from FTSE 100, and we found that board of Capita has 10 members, Pearson 10 members and Diageo 9 members, the average is 9.7 members. In comparison with others, the NYSE average is $12.5, \mathrm{NM}$ is 7.25 , Frankfurt is 7 and Tokyo is 14.3 members. It shows that even with the lack of prescription, the companies opted for a mean number of members.

It is important to point out that some important governance rules are not covered by the other Stock Exchanges. One ruel is Separation of Chairman and CEO that, as said before, should be avoided because concentrates too much power in one person. Even so, only NM and London state that chairman and CEO should not be the same person. A second rule is the existence of outside directors on the board, London SE determines that the chairman should be independent but NYSE is a step forward and states that the majority of the board should be of outside directors. Third and last rule, Board Size should have an appropriate size, it is not easy (if possible) to set a range applicable to all companies, but London lacks prescription when determining a "sufficient" size. NM goes a step forward and set that the minimum number of directors on the board should be 5 . In our sample, the average is higher than 5 , however every company should have a board that is capable to comply with its duties.

London SE determine that listed companies should have at leats Audit, Nominating and Remuneration committees, Frankfurt SE follows a similar policy, determining the existence of two specific committees. Frankfurt and London are not the only Stock Exchanges that set a minimum number of committees, NYSE and TSE also does but they do not specify what committees should exist.

London SE not only showed the highest standard in comparison with all other Stock Exchanges fulfilling 11 out of 14 rules, but also states that the listing company should consider the gender equilibrium on the managerial positions. Toronto SE and Frankfurt SE also have this concern.

\section{Characteristics of Toronto Stock Exchange, TSX}

Toronto Stock Exchange shows to be an interesting case. It has the lowest standards according to our study. Indeed it complies only with items related to disclosures, because the document 
with corporate governance rules (TSX does not have a Code of Corporate Governance) does not require companies to follow specific rules, it requires the companies to disclosure the reasons for such. For example regarding Separation of Chairman and CEO, TSX does not require separation but is mandatory the disclosure when the chairman is the CEO and the reasons for that. This gives company much more freedom than the other systems, but with mandatory disclosures to keep transparency.

As we did with others SE, we took few cases of Toronto SE and looked at the size of the Board of Directors. Altaris Royalty board has 7 members, AltaGas has 9 members, ATS Automation has 7 members and Badger Daylighting has 5 members. The average is 7 members, which is very close from the average of NM and Frankfurt. Both of them comply with the item Board Size. We can, then, infer that in this case the mandatory disclosure of TSX and the board size requirements of Frankfurt and NM had the same effect in companies' policies.

After analyzing the TSX corporate governance structure, one important option appeared for SE when developing corporate governance system. If companies listed in this SE are not mature enough to handle prescriptive rules, the mandatory disclosure can be a suitable option that will not only make company's policies more transparent but also make companies adopt higher governance standards to become more interesting to investor.

\section{CONCLUSION}

As more and more companies do business around the world with their counterparts and governments, it becomes increasingly important to understand the similarities and differences between the corporate governance rules and practices in some Stock Exchange around the world. The state of companies' corporate governance practices and rules has changed dramatically worldwide after the financial crisis in 2008.

We hope that this study allows listed companies to gain an understanding of the state of progress of corporate governance around the world and contributes to have a more efficient corporate governance system. Ultimately, this will result in continuously making profits from business activities and enhancing corporate value.

The discussion on international rules of corporate governance clearly indicates that there is no single framework followed around the world. Reaz and Hossain [1] also claims that there is no single governance style which may be followed in the context of different countries. The main differences and similarities are summarized in appendix 1. Each Stock Exchange has unique characteristics but none of them showed rigid rules, London complied with more items of our proxy but many of them are not prescriptive. On the other hand, NM has the most prescriptive rules but did not cover many items, the others SE are less prescriptive than NM or less compliant than London, thus all Stock Exchanges have areas of development. There are clearly governance differences much more attribute to cultural and country wise dimensions. A comparative picture of the corporate governance scenarios in these six SE researched has the purpose to identifying potential problem areas.

A suggestion for future work is to expand this sample to cover other Stock Exchanges and gain a more thorough understanding of the corporate governance rules and standards.

\section{REFERENCES}

Reaz, M., Hossain, M. (2007). Corporate governance around the world: an investigation. The Journal of American Academy of Business, 11 (2), 169-175. 
Oman, C., Fries, S., Buiter, W. (2003). Corporate governance in developing, transition and emerging-market economies. OECD Development Centre.

IFC (International Finance Corporation) (2014). htttp://www.ifc.org/wps

/wcm/connect/topics_ext_content/ifc_external_corporate_site/corporate+governance/overview/why+corporate +governance.

IBGC (Instituto Brasileiro de Governança Corporativa). (2010). Code of best practice of corporate governance.

OECD The Organisation for Economic Co-operation and Development (2014).

https://www1.oecd.org/daf/ca/2014-review-oecd-corporate-governance-principles.htm.

Gillan, S. L. (2006). Recent developments in corporate governance: an overview. Journal of Corporate Finance, 12 (3), 381- 402. http://dx.doi.org/10.1016/j.jcorpfin.2005.11.002

Malacrida, M. J. C., Yamamoto, M. C. (2006). Corporate governance: information disclosure level and its relation with the stock price volatility on ibovespa. R. Cont. Fin., USP, $65-79$.

Becht, M., Bolton, P., Röell, A. (2003). Handbook of the Economics of Finance, 1. Elsevier, 1-109.

Gregory, H. J. (2002). Comparative matrix of corporate governance codes relevant to the European Union and its member states. Weil, Gotshal \& Manges LLP

FRC (Financial Reporting Council). (2012). https://www.frc.org.uk/Our-

Work/Publications/CorporateGovernance /UK-Corporate-Governance-Code-September-2012.aspx.

Klapper, F. L., Love, I. (2004). Corporate governance, investor protection, and performance in emerging markets. Journal of Corporate Finance, 10 (5), 703-728. http://dx.doi.org/10.1016/S0929-1199 (03)00046-4

Claessens, S., Laeven, L. (2002). Financial development, property rights, and growth. The World Bank Financial Sector Strategy and Policy Department. http://dx.doi.org/10.1596/1813-9450-2924

La Porta, R., Silanes, F. L, Shleifer, A., Vishny, R. (2000). Investor protection and corporate governance. Journal of Financial Economics, 58, 3-27. http://dx.doi.org/10.1016/S0304-405X (00)00065-9

Gompers, P. A., Ishii, J. L., Metrick, A. (2003). Corporate governance and equity prices. Quarterly Journal of Economics, 118 (1), 107-155. http://dx.doi.org/10.1162/00335530360535162

K. H. Chung, J. Elder, J. C. Kim, “Corporate governance and liquidity,” unpublished.

Larcker, D. F., RICHARDSON, F. A., Tuna, I. (2005) HOW important is corporate governance? The Wharton School. http://papers.ssrn.com/sol3/papers.cfm?abstract_id=595821

Bebchuk, L. A., Cohen, A., Ferrell, A. (2009). What matters in corporate governance? Review of Financial Studies, 22 (2) 783-827. http://dx.doi.org/10.1093/rfs/hhn099

BM\&FBOVESPA, (2011). Regulamento de listagem Novo Mercado.

http://www.bmfbovespa.com.br/empresas/download/Regulamento NMercado.pdf.

New York Stock Exchange. (2014). 303A.00 Corporate governance standards.

http://nysemanual.nyse.com/LCMTools/PlatformViewer. asp?

SELECTEDNODE=chp_1_4_3\&manual=\%2Flcm\%2Fsections\%2Flcm-sections\%2F.

German Government Commission. (2014). German code of corporate governance. http://www.dcgk.de//files/dcgk/usercontent/en/ download/code/E-CorpGov_2014.pdf.

Tokyo Stock Exchange. (2013). TSE-Listed companies white paper on corporate governance. http://www.tse.or.jp/rules/cg/white-paper/b7gje60000005ob1-att/b7gje6000003ukm8.pdf.

Financial Reporting Council. (2014). UK Corporate Governance Code. https://www.frc.org.uk/Our-Work/CodesStandards/Corporate-governance/UK-Corporate-Governance-Code.aspx

Ontario Securities Commission. Disclosure of Corporate Governance Practices.

http://www.osc.gov.on.ca/documents/en/Securities-Category5/20141211_58-101_amd-governancepractices.pdf

Dempsey, T. (2012). Corporate governance for main market and aim companies. London Stock Exchange. http://www.londonstock exchange.com/companies-and-advisors/aim/publications/documents/corpgov.pdf. 


\section{APPENDIX 1}

\begin{tabular}{|c|c|c|c|c|c|c|}
\hline $\begin{array}{l}\text { Governance } \\
\text { Rules }\end{array}$ & TSE & NYSE & NM & Frankfurt & London & TSX \\
\hline $\begin{array}{l}\text { Board } \\
\text { Membership } \\
\text { Criteria }\end{array}$ & Not Covered & Not Covered & Not Covered & Not Covered & Based on Merit & Not Covered \\
\hline $\begin{array}{l}\text { Separation of } \\
\text { Chairman and } \\
\text { CEO }\end{array}$ & Not Covered & Not Covered & Mandatory & Not Covered & Mandatory & Not Covered \\
\hline Lead Director & Not Covered & Not Covered & $\begin{array}{l}\text { Not } \\
\text { applicable } \\
\text { because } \\
\text { separation of } \\
\text { Chairman } \\
\text { and CEO is } \\
\text { mandatory }\end{array}$ & Not Covered & $\begin{array}{l}\text { Not applicable } \\
\text { because } \\
\text { separation of } \\
\text { Chairman and } \\
\text { CEO is mandatory }\end{array}$ & Not Covered \\
\hline Board Size & Not Covered & Not Covered & At least 5 & $\begin{array}{l}\text { Several } \\
\text { members }\end{array}$ & Sufficient & Not Covered \\
\hline $\begin{array}{l}\text { Mix of Inside } \\
\text { and Outside } \\
\text { Directors }\end{array}$ & $\begin{array}{l}\text { At least one } \\
\text { outsider }\end{array}$ & $\begin{array}{l}\text { Majority } \\
\text { outsiders }\end{array}$ & $\begin{array}{l}\text { At least 20\% } \\
\text { outsiders }\end{array}$ & Not Covered & $\begin{array}{l}\text { Chairman should } \\
\text { be independent }\end{array}$ & Not Covered \\
\hline Term Limits & 1 year & Not Covered & 2 years & Not Covered & 1 year & Not Covered \\
\hline $\begin{array}{l}\text { Executive } \\
\text { Sessions of } \\
\text { outside } \\
\text { Directors }\end{array}$ & Not Covered & Once a year & Not Covered & Not Covered & Not Covered & Not Covered \\
\hline $\begin{array}{l}\text { Number of } \\
\text { Committees }\end{array}$ & 3 & 3 & Not Covered & $\begin{array}{l}\text { Audit, } \\
\text { Nominating }\end{array}$ & $\begin{array}{l}\text { Audit, } \\
\text { Nominating, } \\
\text { Remuneration }\end{array}$ & Not Covered \\
\hline $\begin{array}{l}\text { Committee } \\
\text { Structure }\end{array}$ & At least 3 & $\begin{array}{l}\text { Audit: At least 3, } \\
\text { Others: Not } \\
\text { Covered }\end{array}$ & Not Covered & Not Covered & $\begin{array}{l}\text { Audit: 3, } \\
\text { Remuneration: 3, } \\
\text { Nominating: Not } \\
\text { Covered }\end{array}$ & Not Covered \\
\hline $\begin{array}{l}\text { Independence } \\
\text { of Committees }\end{array}$ & $\begin{array}{l}\text { Majority } \\
\text { outsiders }\end{array}$ & Entirely outsiders & Not Covered & $\begin{array}{l}\text { Audit: } \\
\text { Independent } \\
\text { Chair } \\
\text { Nominating: } \\
\text { Exclusively } \\
\text { shareholders } \\
\text { representatives }\end{array}$ & $\begin{array}{l}\text { Audit: Entirely } \\
\text { independent, } \\
\text { Remuneration: } \\
\text { Entirely } \\
\text { independent, } \\
\text { Nominating: } \\
\text { Majority } \\
\text { independent }\end{array}$ & Not Covered \\
\hline $\begin{array}{l}\text { Formal } \\
\text { Evaluation of } \\
\text { CEO }\end{array}$ & Not Covered & $\begin{array}{l}\text { Compensation } \\
\text { committee review } \\
\text { and approve }\end{array}$ & Not Covered & Not Covered & $\begin{array}{l}\text { Remuneration } \\
\text { committee } \\
\text { recommendations }\end{array}$ & Disclosed \\
\hline $\begin{array}{l}\text { Executive } \\
\text { Compensation }\end{array}$ & Not Covered & $\begin{array}{l}\text { Compensation } \\
\text { committee } \\
\text { recommendations }\end{array}$ & Not Covered & Not Covered & $\begin{array}{l}\text { Remuneration } \\
\text { committee } \\
\text { recommendations }\end{array}$ & Disclosed \\
\hline $\begin{array}{l}\text { Content and } \\
\text { Character of } \\
\text { Disclosure }\end{array}$ & Not Covered & $\begin{array}{l}\text { Comply with } \\
\text { items b) and c) }\end{array}$ & Not Covered & $\begin{array}{l}\text { Comply with } \\
\text { items a) and b) }\end{array}$ & $\begin{array}{l}\text { Comply with item } \\
\text { c) }\end{array}$ & $\begin{array}{l}\text { Comply with } \\
\text { item b) and } \\
\text { c) }\end{array}$ \\
\hline
\end{tabular}




\begin{tabular}{|l|l|l|l|l|l|l|}
$\begin{array}{l}\text { Shareholders } \\
\text { voting } \\
\text { practices }\end{array}$ & Not Covered & Not Covered & Not Covered & $\begin{array}{l}\text { Each share } \\
\text { carries one } \\
\text { vote }\end{array}$ & Not Covered & Not Covered \\
\hline $\begin{array}{l}\text { Anti- } \\
\text { Takeover } \\
\text { Devices }\end{array}$ & Not Covered & Not Covered & Tag-Along & $\begin{array}{l}\text { Management } \\
\text { Board and } \\
\text { Supervisory } \\
\text { Board, must } \\
\text { submit a } \\
\text { statement of } \\
\text { their reasoned } \\
\text { position so that } \\
\text { the } \\
\text { shareholders } \\
\text { can make an } \\
\text { informed } \\
\text { decision on the } \\
\text { offer. }\end{array}$ & Not Covered & Not Covered \\
& & & & & \\
& & & & & \\
\hline
\end{tabular}

